\title{
EVALUATION OF HYDROCARBON POTENTIALS OF CAMPANIAN SOURCE ROCKS OF NKPORO SHALE (MGBOM SECTION), AFIKPO BASIN, SOUTH EASTERN NIGERIA
}

\author{
Didei, Innocent Sunday and Soronnadi-Ononiwu, Geoffrey Chijioke \\ Department of Geology, Faculty of Science, Niger Delta University, Wilberforce Islaand, Amassoma, \\ Bayelsa State
}

Keywords: Total Organic Carbon Content, Organic Matter, Soluble Organic Matter, Nkopro, Shale, Hydrocarbon

\begin{abstract}
This work evaluated the hydrocarbon potential of Campanian source rocks of Nkporo Shale (Mgbom section) using parameters like Soluble Organic Matter (SOM), Total Organic Carbon (TOC) and Organic Matter Quality (OM) on samples taken from the section. The Nkporo Shale is dark grey in color and is highly fissile with interbeds of sandy shale, siltstone and mudstone. The investigated section exposed at Mgbom, Ebonyi State consisted of the Nkporo Shale, a formation in the Lower Benue Trough. The rocks are fairly to moderately rich in organic matter and can therefore be considered as potential source rocks. TOC analysis on sample revealed from the Mgbom Section in the range of $0.51 \mathrm{w} \%-1.02 \mathrm{wt} \%$ which exceeds the minimal amount needed for a potential source rock. The SOM ranges from $67 \mathrm{mg} / \mathrm{kg}-165 \mathrm{mg} / \mathrm{kg}$ and the OM ranges from $77.40 \%-89.30 \%$ indicating that the source rock is fairly rich in hydrocarbon content.
\end{abstract}

\section{INTRODUCTION}

Notable scholars had carried out intensive research and studies on the geology of Santonian to Maastrichtian sediments in the Lower Benue Trough of Nigeria in the past and in the present; they reported that the Agwu and Nkporo Shale constituted the main source and seal rock and that the percentage of the organic carbon to the Santonian Shales was quite comparable to those of the nearby Niger Delta. Unomah and Ekweozor (1983) have assessed the petroleum source rock potential of the Nkporo Shale and concluded that the Organofacies are provincial with the Calabar Flank having the highest oil prone marine derived Organic Matter (OM). Nkporo Shale in the Anambra Basin and Afikpo Syncline was reported to contain mainly terrestrially derived organic matter that is essentially gas prone.

The organic facies, hydrocarbon source potential and reconstruction of the depositional environment of the Campano - Maastrichtian Nkporo Shale have been studied by Akaegbobi and Schrnitt (1998). The result showed that the source rock composed of type III/II kerogen 


\section{LOCATION AND ACCESSIBILITY OF STUDY AREA}

Afikpo North east lies between latitude N 5 53'35", and longitude E7 $56^{\prime} 14^{\prime \prime}$ at the south of Ebonyi state, South East Nigeria, covering a land mass of $635.4 \mathrm{~km}$ square. The area is accessible by a good road network connecting the town to the major cities like Abakaliki and foot paths internally connecting the various communities together. The area is accessible by road and footpaths. The primary access is through either the Abakaliki - Afikpo express road or through the Ameseri Akaeze road; it is also accessible through cross river from Ndibe beach road. Other access to the study area is made possible through the minor roads linking the various towns and communities around the area. Footpaths and feeder roads give accessibility to the study area and its environs.

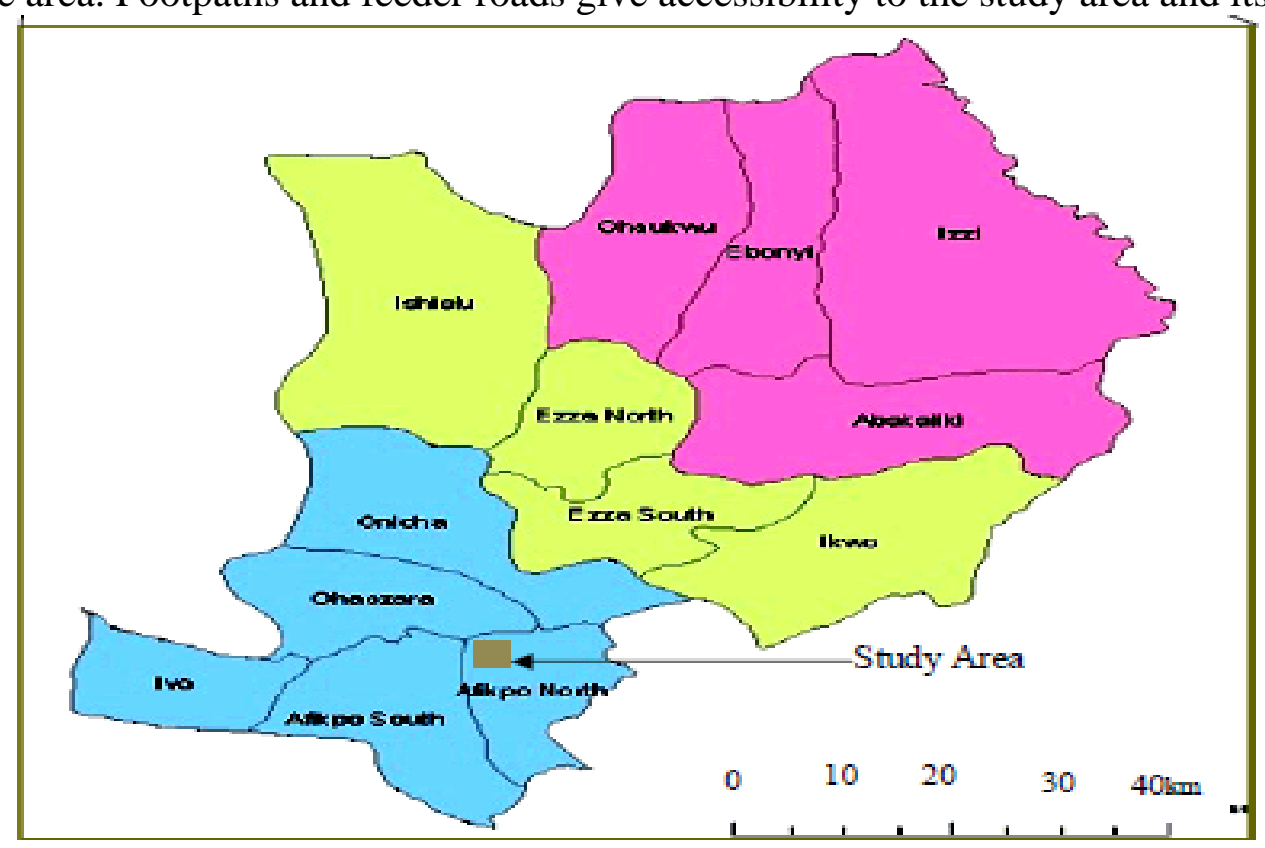

Fig 1. Map of Nigeria showing the study area, Afikpo-North LGA South Eastern Nigeria (Ogbonnaya, 2012)

\section{TOPOGRAPHY AND DRAINAGE OF THE STUDY AREA}

Afikpo is an undulating terrain with lateral extensive outcrops and formations covering large land masses. The major outcrops found in this area are the sand stones and shale, mudstone, siltstone. The shale's were subjected to denudation because of its low resistance thereby forming valleys and plains but the sandstones which appeared to be more resistant to denudation formed the hills and ridges. The shale are separated by smaller stream, most of which are seasonal and thus come out from the sand stone ridges. Erosion is well pronounced in this area. Afikpo is a sub basin but in terms of its local topography, it is an undulating terrain having its highest elevation as 450 feet and its lowest elevation as 50 feet above sea level respectively.

The drainage pattern of Afikpo is controlled by Ndibe beach, Ozizza beach and tributaries from Iyowa and Iyogae River which flows eastward to Ebonyi River running from Akpoha towards a Y junction flowing into Cross Rivers and depositing large amounts of sand sediments as a result of the decrease in the intensity or energy of the flowing river. However, Cross Rivers empties into the South Atlantic Ocean. The North Eastern part of Afikpo also possesses a good drainage system which tends to empty itself through run-offs and channels into the Asu River which in turn empties itself into the Cross River which open up to the South Atlantic Ocean. 


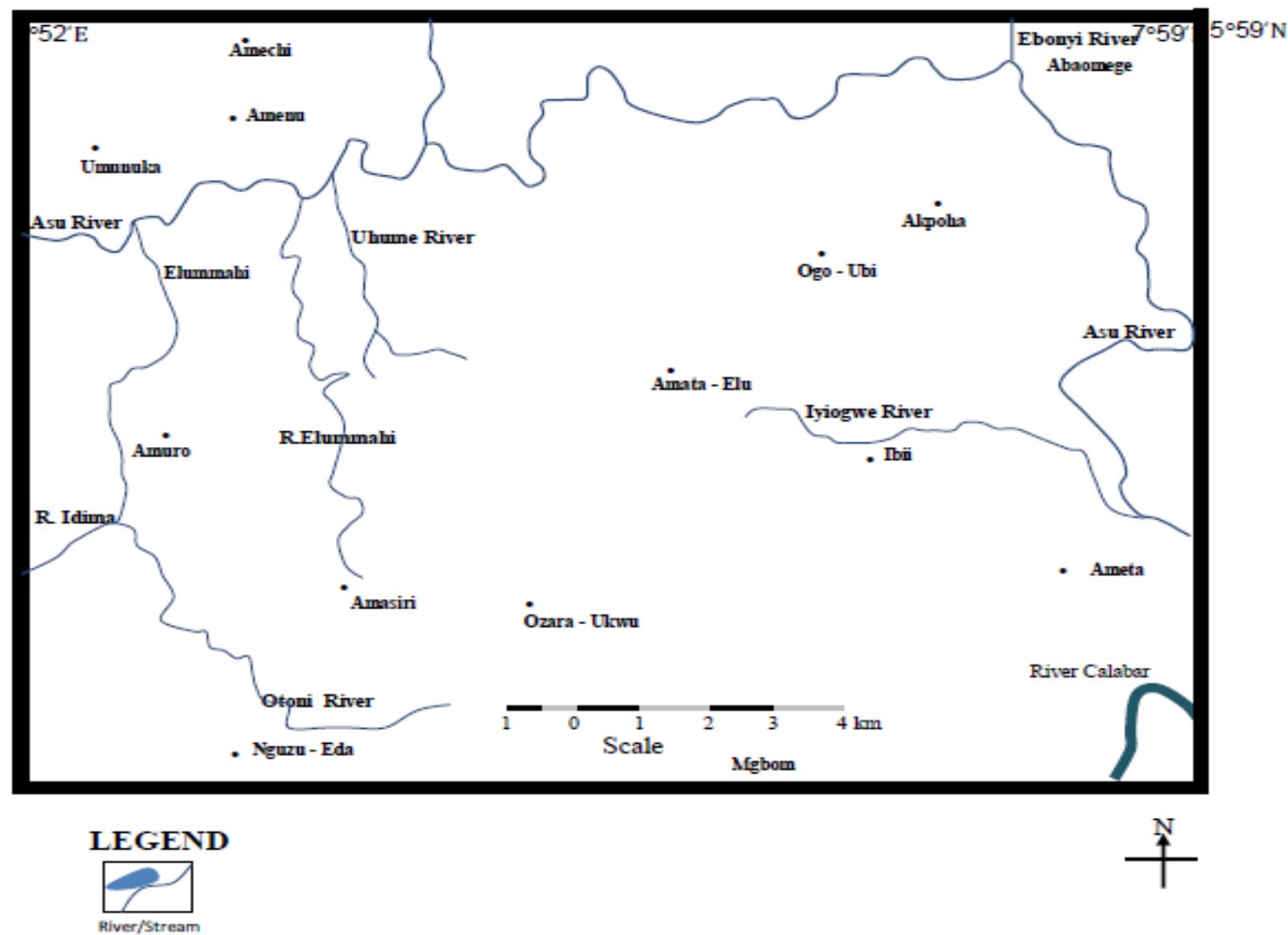

Fig 2. Drainage map of the study area showing the major rivers and their distributaries (Ogbonnaya, 2012)

\section{GEOLOGICAL SETTING}

The study area is located in the southern part of the Anambra Basin and covers about 220km2; the basin is bounded to the south by the Niger Delta Hinge line. It extends north-westward into Niger Valley, northward to the Jos massive and north-eastward as far as Lafia, the eastern and western limits of the Basin are defended by the Abakaliki Anticlinorium and Ibadan Massive respectively. The structural evolution of the Anambra Basin has been described by Ojo (1988), Poplf (1990), Blink and Farheard (1992), Obi et al (2001) and Obi and Okagbue (2004). The origin of the basin is generally believed to be linked to the Santonian tectonics of the Abakaliki -Benue Basin, during which an N-S compression between the African and European plates folded the Abakaliki Anticlinorium.

\section{TECTONIC SETTING}

Prior to the tectonic event, the Anambra Basin was thinly covered by sediments, the folding of the anticlinorium laterally shifted the deposit into the Anambra Platform which then began to accumulate sediments shed largely from the Abakaliki Anticlinorium (Murat, 1972).

Over 2500m of sediments that accumulated during the Campanian-Maastrichtian period is represented by the Nkporo Group, comprising the Nkporo Formation. Owelli Sandstone (including Lokoja and Lafia Sandstone) and Enugu Shale (Reyant 1965), the Nkporo Formation with an estimated subsurface thickness of 1000m (Agagu and Ekweozor, 1982, Agagu et al, 1985) outcrops mainly in the area south of Awgu where it consists of a succession of ammonite bearing marine shale. Limestone lenses and sandstone that successfully overship the Coniacian-Santonian Awgu 
Formation, Turonian Ezeaku Formation and the Albian Asu River Group, the Nkporo Group is represented by the Owelli Sandstone and Enuu Shale. The Owelli sandstone consists of medium to coarse-grained prominently cross-stratified, feldspathic sandstone unconformably overlies the Awgu Formation (Agumanu, 1993) in the region, north of Awgu, the Owelli sandstone is directly overlain by the Enugu shale comprising soft grayish blue or dark grey carbonaceous mudstone and fine-grained sandstone that are well exposed along Enugu.

The Enugu shale is associated with extension synsedimentary deformation structures (Nwajide and Reijers, 1996, Obi and Okagbue, 2004). South of Awgu, the Nkporo Formation is directly succeeded by the basinal facies of the coal Muma Formation (Reyant, 1965), the latter comprises rhythmic alternation of thick carbonaceous shales and oolithic sandstones that pass upward into mainly fine-grain and well sorted sediments.

\section{STRATIGRAPHY OF THE STUDY AREA}

\begin{tabular}{|c|c|c|c|c|c|c|c|}
\hline \multirow{2}{*}{\multicolumn{2}{|c|}{$\begin{array}{l}\text { STAGES \& } \\
\text { EPOCHS }\end{array}$}} & \multirow{2}{*}{$\begin{array}{l}\text { LOWER BENUE } \\
\text { ANAMBRABASIN }\end{array}$} & \multicolumn{2}{|c|}{ MIDDLE BENUE } & \multicolumn{2}{|c|}{ UPPER BENUE } & \multirow{2}{*}{$\begin{array}{l}\text { LOWER BENUE } \\
\text { TROUGH } \\
\text { AFIKPOBASIN }\end{array}$} \\
\hline & & & LAFIA AREA & BASHAR AREA & GOMBE AREA & LAUAREA & \\
\hline \multicolumn{2}{|r|}{ Eocene } & Ameki Fm. & \multirow[b]{2}{*}{ Volcanics } & \multirow{2}{*}{ Kerri Kerri Fm } & \multirow{2}{*}{ Kerri Kerri Fm } & \multirow{2}{*}{ Volcanics } & Ameki Fm. \\
\hline & Paleocene & Imo Shale & & & & & Imo Fm \\
\hline \multirow{3}{*}{\multicolumn{2}{|c|}{ MAESTRICHTIAN }} & Nsukka Fm. & \multirow[b]{3}{*}{ Lafia Formation } & \multirow[b]{2}{*}{ Gombe Sandstone } & \multirow[b]{2}{*}{ Gombe Sandstone } & \multirow[b]{2}{*}{ Lamja Sandstone } & \multirow{3}{*}{$\begin{array}{l}\text { Nsukka Fm. } \\
\text { Ajali Fm. } \\
\text { Mamu Fm. }\end{array}$} \\
\hline & & Ajali Sandstone & & & & & \\
\hline & & Mamu Formation & & \multirow{3}{*}{ Unnamed Marine } & \multirow[b]{3}{*}{ Pindiga Formation } & & \\
\hline \multirow{3}{*}{8} & Campanian & \multirow{2}{*}{ Enugu Shale } & & & & & \multirow{2}{*}{ Nkporo Fm } \\
\hline & Santonain & & & & & & \\
\hline & Coniacian & Awgu Formation & Awgu Formation & & & & \multirow{3}{*}{ Eze Aku Group } \\
\hline$w^{2}$ & Upper & \multirow{2}{*}{ Eze Aku Shale } & & & & & \\
\hline & Lower & & Eze Aku Fm. & & & & \\
\hline \multicolumn{2}{|c|}{ CENOMANIAN } & Odukpani Fm. & Keana Formation & & & & \multirow{2}{*}{ Asu River Group } \\
\hline ALBIAN & Upper & Asu River Group & Asu Awe Formation & Pre-Bima Sediment & Pre-Bima Sediment & Pre-Bima Sediment & \\
\hline \multirow{2}{*}{\multicolumn{2}{|c|}{ PRECAMBRIAN }} & \multicolumn{5}{|c|}{ Basement Complex } & Basement \\
\hline & & HOQUE (1977) & OFFODILE (1976) & AYOOLA (1978) & \multicolumn{2}{|c|}{$\begin{array}{l}\text { CARTERET AL (1963) } \\
\text { CRATCHELY \& JONES (1965) }\end{array}$} & ODIGI, 2007 \\
\hline
\end{tabular}

Fig 3. Stratigraphic Succession in the Lower Benue Trough (Odigi, 2007)

\section{METHODOLOGY AND MATERIAL}

Five samples were obtained from Nkporo Shale at Mgbom at $16 \mathrm{ft}$ interval and were carefully placed to avoid contamination. The samples were hard thickly laminated and fissile with texture indicative of low permeability. The sample is attributed to the Campanian-Maastrichtian marine and paralic siliciclastic strata which are overlain by the coal measures of the Mamu Formtion. The method involved measurements, documentation of sedimentologic features and sampling of the surface lithology of the Mgbom Section. 


\section{TECHNIQUE USED}

The sediments were processed for their palynomorphs contents. Samples preparation was carried out using conventional macerations technique for recovering acid using insoluble organic walled microfossils from sediments. Each sample was digested for 30minutes in $40 \%$ hydrochloric acid to remove traces of carbonates for 72 hours in $48 \%$ hydrofluoric acid for removal of silicate. The extracts were washed, dried and crushed.

\section{RESULTS AND DISCUSSION}

\section{LITHOFACIES}

The samples are Campanian-Maastrichtian in age. It consists of three distinct colors. Sample 1 and 2 were dark grey, sample 3 was light brown, sample 4 was dark grey and sample 5 was dark brown. The topmost part of the Mgbom Section was covered by lateritic soil.

\section{ORGANIC RICHNESS}

The Total Organic Carbon (TOC) content of the shale samples from the Mgbom Section ranges from 0.51 to $1.02 \mathrm{wt} \%$ (Table 1 ). These amounts of organic carbon exceed the minimal $0.5 \mathrm{wt} \%$ threshold for a potential source rock indicating that the shale can generate oil and gas. The highest value of $1.02 \mathrm{wt} \%$ is observed in the Mgbom Section.

\section{TOTAL ORGANIC CARBON (TOC) CONTENT}

Total organic carbon (TOC) content is the measure of the organic richness of a rock. It is the quantity of organic carbon (both kerogen and bitumen) in a rock sample. TOC is reported in weight percent (wt\%) carbon (eg. 1.0wt\% carbon means that in 100 grams of rock sample, there is one gram of organic carbon). TOC is a useful quantitative measure of petroleum. The worldwide average TOC of all shale is about $0.9 w t \%$ and the average TOC of source rock shale is $2.2 \mathrm{wt} \%$ (Miles, 1989), the average TOC of carbonate source rock is $1.9 \mathrm{wt} \%$ and $0.7 \mathrm{wt} \%$ repetitively. The worldwide average TOC of all source rock is $1.8 \mathrm{wt} \%$, a value much higher than minimum value for defining potential source rocks.

TABLE 1 showing the samples, color, SOM, OM, TOC and depth.

\begin{tabular}{|c|c|c|c|c|c|}
\hline DEPTH & SAMPLE IDENTITY & COLOR & TOC (wt\%) & SOM (mg/kg) & OM (\%) \\
\hline \multirow{6}{*}{$\begin{array}{l}30 \\
25 \\
20 \\
15 \\
10 \\
5 \\
0\end{array}$} & SAMPLE 5 & DARK BROWN & 0.51 & 67.50 & 87.30 \\
\hline & SAMPLE 4 & DARK GREY & 0.54 & 165.00 & 77.40 \\
\hline & SAMPLE 3 & LIGHT BROWN & 0.48 & 82.50 & 89.30 \\
\hline & SAMPLE 2 & DARK GREY & 1.02 & 75.00 & 85.70 \\
\hline & SAMPLE 1 & DARK GREY & 0.93 & 157.50 & 85.00 \\
\hline & & & & & \\
\hline
\end{tabular}

However, high TOC is not a sufficient condition for oil generation. Coals usually have high TOCs that exceed $50 \mathrm{wt} \%$ but do not generate oil except when rich in liptinite, indicating the relevance of maceral composition. In contrast, deltaic sediments may have TOCs below $1 \mathrm{wt} \%$ but generate commercial accumulations of petroleum due to deposition of large volumes of sediments, as seen in the Niger Delta. High TOC content in shale indicates favorable conditions for preservation of organic matter produced during deposition. This may be related to the redox condition with high oxygen favoring organic matter oxidation, but also amount of organic matter 
produced.

\section{ORGANIC MATTER QUALITY}

Water, organic matter, carbonate mineral, and siliciclastic diatom content are estimated by sequentially measuring weight loss in sediment core subsamples after heating at selected temperatures. A compositional profile can be generated rapidly and for very low cost. This profile is sufficient to develop a general sense of core stratigraphy and is often sufficient for correlation between cores. The method used in this study is the Loss on Ignition Method. The OM ranges from $77.40-89.30 \%$ indicating that the source rock is fairly rich in hydrocarbon content.

\section{SOLUBLE ORGANIC MATTER}

In this study, Dilution method was used. The higher the change in color, the higher the SOM, there was no significant color change in the samples from the Mgbom section. The SOM ranges from $67 \mathrm{mg} / \mathrm{kg}-165 \mathrm{mg} / \mathrm{kg}$ indicating that the rock is fairly rich in hydrocarbon.

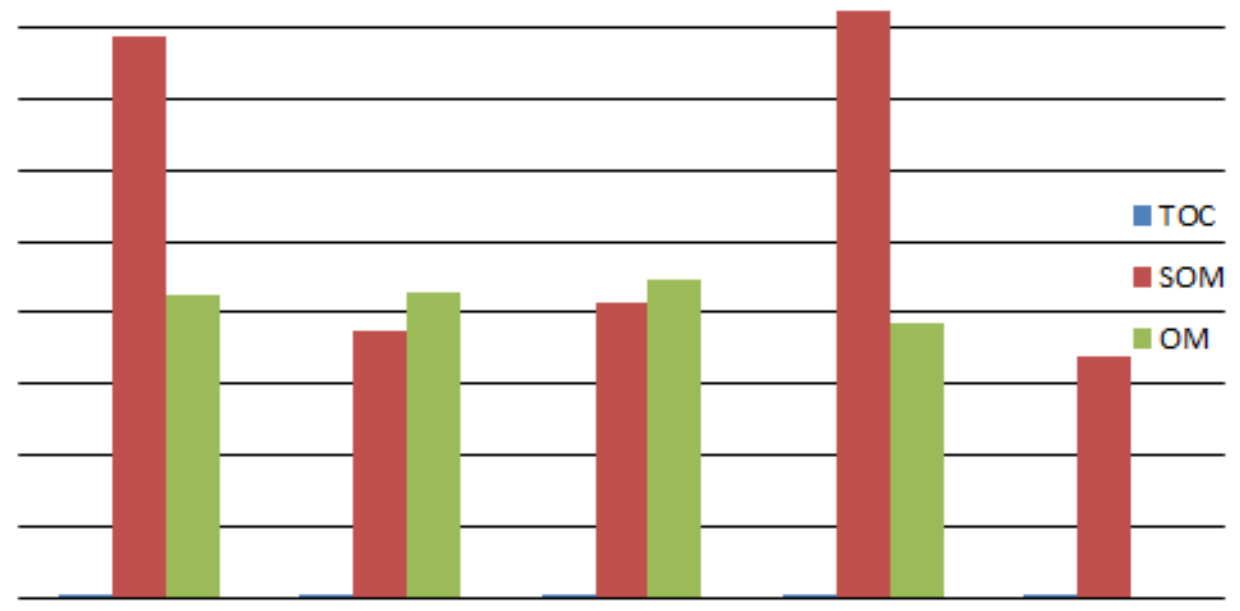

Fig 4. A histogram showing the TOC, SOM and OM of the samples

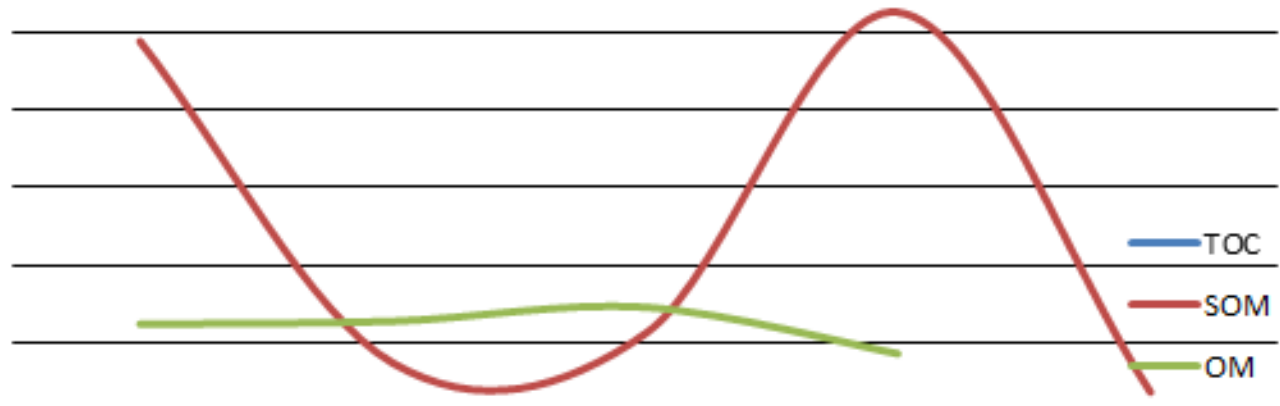

Fig 5. A graph showing the relationship of the SOM, TOC and OM of the sample 


\section{CONCLUSION}

The investigated section exposed at Mgbom, Ebonyi State consist of the Nkporo Shale, a formation in the Lower Benue Trough. The rocks are fairly to moderately rich in organic matter and can therefore be considered as potential source rocks. TOC analysis revealed samples from the Mgbom Section range from 0.51 to $1.02 \mathrm{wt} \%$ which exceeds the minimal amount needed for a potential source rock. The SOM and OM analysis revealed that the samples are fairly to moderately rich in organic matter. The TOC analysis was done by rapid oxidation method, SOM analysis was done by dilution method and the OM analysis was done by Loss on Ignition Method. The SOM ranges from $67-165 \mathrm{mg} / \mathrm{kg}$ and the OM ranges from $77.40-89.30 \%$ indicating that the source rock is fairly rich in hydrocarbon content.

\section{REFERNCES}

[1] Agagu, O. K., 1978. Geology and Petroleum potentials of Santonian to Maastrichtian sediments in the Anambra Basin, Eastern Nigeria. Unpublished . Ph.D Thesis, University of Ibadan, Nigeria, pp:214

[2] Agagu, O. K., and C. M. Ekweozor, 1989. Petroleum geology of the Santonian sediments in the Anambra Syncline, Southeastern Nigeria. Nig J. Min, Geol., 19: 52-61

[3] Agagu, O. K., E. A. Fayose and S. W. Petter, 1985. Stratigraphy and sedimentation of Santonian Anambra Basin of the Eastern Nigeria, J. Minerial, Geol., 22:25-36

[4] Akaegbobi, I. M. and M. Schmitt, 1998. Organics facies, Hydrocarbon source potential and the reconstruction of the deposition environment of the Campo-Maastrichtian Nkporo Shale of the Cretaceous Anambra Basin. NAPE Bulletin, 13: $1-19$

[5] Akaegbobi, I. M. and Boboye, 1999. Textural, structural features and microfossil assemblage relationship as a delineating criteria for the stratigraphic boundary between Mamu Formation and the Nkporo Shale within the Anambra Basin, Nigeria. NAPE bulletin, 14: 176-191

[6] Avbovbo, A. A. and O. Ayoola, 1981. Petroleum prospects of the Southern Nigeria's Anambra Basin. Oil and Gas Journal, 79: 334-347

[7] Beckhill, J. 1989. The origin and evolution of Cretaceous Benue Trough. Nigeria. African Earth sci., 8: $251-282$

[8] Burke, K., T. F. J. Dessauvagie and A. J. Whiteman, 1972. Geological history of the Benue Valley and adjacent areas. In African Geology (Eds). Whiteman, A. J. and T. F. J. Dessauvagie, Ibadan, pp: 187-206

[9] Ekweozor, C. M. and J. R. Gormly, 1983. Petroleum geochemistry of the early Tertiary shales penetrated by the Akwa Two well in the Anambra Basin, Southeastern Nigeria. J. Petroleum Geol., 6: 207-216

[10] Eseme, E., Agyingi, C. M., Foba-Tedo J., African Earth Sci, 2002, 35: 467-476

[11] Eseme, E., Littke, R., Agyingi, C. M. J Petrol Geosci 2006, 12, 69-74

[12] Kogbe, 1976. Paleogeographic History of Nigeria from Albian Time. In : Kogbe, C. A. (Ed), Geology of Nigeria. University of Ife, pp237-252

[13] Nwajide, C. S. and T. J. A. Reijers, 1997. Sequence architecture of the Campanian Nkporo and Eocene Nanka Formations of the Anambra Basin, Nigeria. NAPE Bulletin, 12: 73-87

[14] Petters, S. W., 1978. Stratigraphic evolution of the Benue Trough and its implication for the Upper Cretaceous Paleogeography of the West Africa. J. Geol, pp : 331-332

[15] Reyment, R. A., 1965. Aspects of the Geology of Nigeria. University of Ibadan Press, Ibadan.

[16] Short, K. C and A.J. Stauble, 1967. Outline of geology of Niger Delta. Am. Assoc. Pet Geol, Bulletin, 62: 761-779

[17] Unormah, G. I. and C. M. Ekweozor, 1993. Petroleum source rock assessment of the Campanian Nkporo Shale, Lower Benue Trough, Nigeria. NAPE Bulletin, pp: 172-186 